(Rev. 2/03)

\title{
Global Franchising: Current Status and Future Challenges *
}

\author{
By \\ Richard C. Hoffman \\ Professor \\ Perdue School of Business \\ Salisbury University \\ Salisbury, MD 21801 \\ 410-548-5398 \\ Fax 410-546-6208 \\ rchoffman@salisbury.edu \\ and \\ John F. Preble \\ Associate Professor \\ Dept. of Business Administration \\ University of Delaware \\ Newark, DE 19716 \\ (302) 831-1778 \\ Fax (302)831-4196 \\ preblej@be.udel.edu
}

* This study was partially funded by a Summer Research Grant from the Perdue School to the first author.

Published Citation: Hoffman, R.C. and Preble, J.F. 2004. Global franchising: Current Status and Future Challenges. Journal of Services Marketing , 18(2): 101-113. (Lead article). 


\title{
Global Franchising: \\ Current Status and Future Challenges
}

\begin{abstract}
About a decade ago positive predictions were made regarding the international growth of franchising. This study was undertaken to examine the actual growth and development of franchising globally during the nineties. Using survey and archival data findings regarding the state of franchising in 40 countries are presented. Franchising has met or exceeded the growth expectations, generating an average of $\$ 3.7$ billion in annual sales in the nations investigated. However, considerable regional differences in franchising activities do exist. The business sectors experiencing the most franchising growth are retail and restaurants. Franchising firms tend to export their business formats to neighboring countries or to countries with similar cultural characteristics. Operational concerns regarding legal and social issues across borders are also examined. Implications for practice and research are discussed.
\end{abstract}

Key words: Franchising, international markets, global growth, services, future trends. 


\section{Global Franchising: Current Status and Future Challenges}

As franchise sectors mature in the home market, franchisors who wish to grow must look to international markets. Market saturation (Alon and McKee, 1999) is increasingly becoming the case for franchisors in the United States, Canada, Western Europe and Japan. For example, U.S. franchising revenues have grown to $\$ 1$ trillion or about 50 percent of all retail trade. By way of contrast, China, with about one-quarter of the world's population, has a soaring middleclass and is considered the most under-retailed country in the world . Eastern Europe, the Middle-East and other parts of Asia are also significant regions for franchising growth (Swartz, 2000). In fact, the growth potential for franchising worldwide is considered by some to be exponential.

Seven years ago Preble and Hoffman (1995: 87) conducted a global survey of franchise associations around the world. Their survey provided a status report on franchising among thirteen nations. The survey concluded by stating that, "The prospects for franchising on a global basis seem great." In an earlier article the same two authors forecasted that, by the year 2000 , sixty percent of US franchisors will have expanded internationally, and the growth by non-US franchisors was expected to grow at a faster rate (Hoffman and Preble, 1993; Welch, 1992). Thus, the dawn of the new century seems to be an opportune time to take stock of the growth and development of franchising worldwide using a larger sample than the previous study. Before describing the study, we review some trends that lead us to believe that there has been a substantial expansion of franchising in recent years. 


\section{INTERNATIONAL TRENDS FAVORING FRANCHISING}

Amos (2001) believes franchisors must have a strategic plan that incorporates international opportunities as we move closer to a global marketplace and global economy. Indeed, the integration of the world economy, i.e., globalization, is a pervasive force in the world today (Micklethwait and Wooldridge, 2000). Increased market liberalization (e.g., EU, NAFTA, WTO) has created unprecedented market opportunities for trade, foreign direct investment, intellectual property transfers, and capital flows. The adoption of democratic political systems, and a rise in market capitalism in many formerly communist or socialist countries further expands those opportunities. The explosive growth in information and communications technology, as well as, improved long-distance travel has made the world smaller, more interconnected and interwoven. Taking advantage of these trends, multinational organizations, in numerous industries, have pursued global expansion strategies and successfully spread their operations and management around the globe. Franchising is somewhat uniquely positioned to both ride this global wave, as well as to help propel it.

The franchising concept is a highly flexible and adaptable one and ideally suited for developing service economies (Connell, 1999). While franchising is well established in developed nations, it also works advantageously in transitional economies, such as the Czech Republic, Hungary and Slovenia. These countries are without a history of entrepreneurship, and franchising provides the necessary structure and support that otherwise would be lacking (Chapman, 1997). Franchising may also provide a source of competitive advantage for entrepreneurial endeavors by using a proven service/product and brand name (e.g., Preble and Hoffman, 1994). Amos (2001) also sees franchising as a "translatable" concept enabling any business to adapt to different cultures and business regulations around the globe, but it takes a 
different set of capabilities to be successful overseas (Shane, 1996). Franchising works well throughout the business cycle. In good times franchised businesses increase with the expansion in demand for goods and services. During a downturn in the economy, interest in franchising a business often increases as displaced white-collar workers (e.g., dot.com workers or middle-level managers) see franchising as a desirable option (Whittemore, 1993).

Advances in technology and telecommunications are positive developments for international franchise development. The internet, fax machines, company wide intranets, cell phones, etc., all make it easier for companies with a wide geographic spread to stay in constant contact, at a reasonable cost. For franchised organizations, in particular, this dramatically improves long-distance monitoring of franchised units, as well as, lowering monitoring costs. This also allows smaller-sized franchised companies to expand globally more quickly, where in the past, this would have been cost-prohibitive (Amos, 2001).

A country's regulatory framework as well as the government's actions or inactions can foster or hinder franchise development in any nation. Although numerous barriers remain to the internationalization of services (Samiee, 1999), especially in Asia (Swartz, 2000), government bodies in countries such as Malaysia and Singapore are taking action to open doors to franchising (Amos, 2001). Increasingly, nations are recognizing that franchising activity can be used to help effectively grow their economies. As a result, several governments have encouraged franchising in their nations by passing laws, establishing organizations, and developing support programs such as conferences and exhibitions (Swartz, 2000). Middle Eastern governments have been quite aggressive in facilitating the expansion of franchising in the region with major investments to upgrade infrastructures (e.g., energy, education, healthcare, telecommunications, and highways) (Chaplin, 1998). Governments are also providing a growing 
number of tax-free facilities and improved intellectual property rights protection so critical to franchising. Egypt has set up a Social Fund for Development to help promote small business, mostly single-unit franchises (Chaplin, 1998). Of course, many middle-eastern countries have rapidly growing middle-classes that are eager to spend on consumer and leisure franchise offerings.

Middle-class populations are emerging in numerous nations around the globe and are likely to fuel franchising's growth in the next decade. The middle-class is often concerned with continuing their upwardly mobile path through conspicuous consumption of a vast array of goods and services that will signal their prosperity and save them time ( Hoffman and Preble, 1993). Some 30 million middle-and upper-class Indonesian consumers are shopping like never before and have changed their consumer behavior to be more like their counterparts in Asia: market savvy, trend-conscious, and demanding (Montlake, 2001). China's middle class is some 70 million strong with average incomes between $\$ 3,000$ to $\$ 5,000$ a year (Hunt, 2001). General Motors, who has a major joint venture in China, believes that China's middle class will begin to increase exponentially in size and wealth in the years ahead (Asia Week, 2001). In the second most populous nation in the world, India, deregulation has aided franchising's prospects as it can be applied to an estimated 300 million middle-class consumers (Hough, 1995). Twenty to 25 percent of all households in Russia are now part of a fledgling middle-class (IPR, 2000) and some $40 \%$ of Brazil's population of 170 million is considered middle-class (Hemlock, 2000). A combination of pent-up demand and a proclivity to purchase global brand names by the world's emerging middle-classes should propel franchising's growth internationally well into this century. 


\section{RESEARCH QUESTIONS}

Having just examined a large number of trends and developments that should positively impact on franchising's growth and global diffusion, we will now present the questions guiding this research. The basic question that guided this study was: What is the current status of franchising globally as we begin the new millennium? The large number of trends and developments described in the previous section leads to the following:

What is the extent of growth and development of franchising globally?

Responses to this question will provide a statistical profile of franchising characteristics and growth globally.

What are the major worldwide product/service and geographic markets for franchising? In domestic markets franchising appears strong in certain product/service segments, we intend to determine if this is the case globally. The pattern of international expansion will be examined both in terms of the national origin of firms exporting their franchises as well as the country of origin of those importing their business concepts into a given country.

What are some of the key operational issues for franchisors doing business in different world regions? Environmental characteristics such as laws, culture and ethics vary from nation to nation. This study seeks to identify the operational issues that are most salient to the franchising sector in various parts of the globe.

What are the opportunities and challenges facing franchisors in various parts of the world? This section will explore economic opportunities and future challenges for franchisors in various world regions.

Responses to these questions should provide a current status report of franchising worldwide.

\section{THE STUDY}

We decided to use the same instrument (described later) directed at the same population as the earlier global survey (Preble and Hoffman, 1995, 2002). The only change to the earlier instrument was the addition of an open-ended question regarding challenges affecting the franchising sector in a given country over the next five years. The survey was mailed or faxed to directors of franchise associations in each of 59 countries. Six associations were found to be no 
longer operating at given addresses reducing the overall population to 53. Seven years earlier only 23 such associations were identified. The number of active associations operating today represents a $130.45 \%$ increase in franchise organizations globally. The associations were listed in Dixon (2001) and addresses were verified at the International Franchise Association's web page at www.franchise.org. Most of the associations are members of the World Franchise Council. Questionnaires were faxed to associations with fax a number; otherwise, they were mailed to those without one. Two follow-up faxes or mailings were sent at four week intervals. A total of eighteen associations provided complete data via the survey. Using the questionnaire, data on another 22 associations was compiled from annual reports, association web sites, and government documents (i.e., NTDB Reports, U.S. State Department, and World Exports). Thus, the final sample represents franchising sector data from 40 nations or $75 \%$ of the known population of countries with organized franchise sectors.

Instrument: A two-page survey consisting of 14 questions was used to obtain most of the data for this study. The survey was in English because it is the international language of commerce and most associations have an English-speaking staff member. Seven short-answer format questions sought information on association age, membership, number of franchisors and franchisees, annual sales, and on the leading sectors for franchising growth . Two short-answer questions sought information on the top three nations to which local franchisors exported their franchises as well as the top three countries which imported franchised businesses into the country surveyed. Using three open-ended questions, the survey then sought information on operational issues facing franchisors in the focal country regarding tax/legal considerations, cultural-social issues, and ethical practices; one close-ended question explored economic opportunities available to franchisors. Finally, the respondents were asked one open-ended 
question regarding the important challenges affecting franchise companies in their country over the next five years.

\section{FINDINGS}

Some 40 nations appear to have a substantial and active franchising industry replete with a trade association of their own. These nations represent six continents (see Appendix A). Our results will be discussed both on an overall basis and by continent/region to reveal the diversity of franchising activity. Africa and Oceania have been combined as there are only two African nations in our sample along with the two nations of Australia and New Zealand. We recognize that these regions have vast differences, but each of these regions do not have sufficient country representation to warrant separate treatment.

"take in Table 1 here"

Overall, the nation's sampled are middle income, literate and have fairly good access to media (see Table 1). The sampled nations have a median population of over 29.5 million with a gross domestic product per capita of $\$ 10,650$. Seventy-four percent of their literate $(95 \%$ literacy rate) populations live in urban areas. Fifty-five percent work in the service sector, and there are 44 radios for each 100 persons (see Table 1). These are all characteristics favorable for franchising activity.

Regional differences do exist, however. The largest populations are found in Asia; the wealthiest, best educated and most service-oriented are in Europe. The most urbanized nations are located in South America while those with the best media access are in North America with about one radio for every single person. 
What is the extent of growth and development of franchising globally?

The growth and development of franchising is illustrated in Table 2. All forty nations have formed franchise associations. This is an indication that there is a sufficient critical mass of franchise activity to warrant forming their own trade association. These associations are fairly recent with over half having been founded since 1989. Some of the older associations were founded in North America specifically in the U.S. in 1960. The newest association was founded last year, 2001, in Egypt. Regionally, Asia has the newest organized franchise sector based on median age of their trade associations with half having been founded since 1992. South America follows closely behind with a median founding date of 1991. An average 108 firms are members of their national franchise associations. There is a wide range in size of associations. Bulgaria reported a low of two members while Canada boasts 1300 members. The highest average memberships are in North America; whereas, the lowest are in South America.

"take in Table 2 here"

The total number of franchising companies, franchise units and sales provide strong indication of the size of the franchise sectors around the world. Globally, these nations report a median 265 franchisors who run a median 14,561 units that generate 3.7 billion dollars in sales representing a median $10 \%$ sales increase over the previous year (see Table 2). Thus, franchising represents a significant economic activity among the nations studied. North America reports the highest median number of franchisors at 500 followed by Africa/Oceania, Asia, Europe, and South America reporting only 80 franchisors. On average, in terms of franchise units, however, Asia reports the highest median number at 24,000 followed by North America $(20,000)$, Africa/Oceania, Europe, and lastly South America with a median of 1200 units. 
In terms of sales, North America reports the highest median sales at $\$ 32.3$ billion followed by Africa/Oceania at $\$ 8.4$ billion, Europe ( $\$ 7.8$ billion), Asia ( $\$ 2.4$ billion) and South America with median sales of \$218 million. Individually, the United States leads all nations with a total number of 1500 franchisors, operating 316,000 units, and generating $\$ 1$ trillion in sales in 2000. Other nations with significant numbers of franchisors include Canada $(1,300)$, Japan (968), and Brazil (894). In terms of units, Japan was second behind the U.S. with 198,328 followed by Canada (80,000), and Australia with 49,400 units. In terms of sales Japan was a distant second to the U.S. with $\$ 156$ billion, followed by Australia's \$76.5 billion, and China with a reported $\$ 63.2$ billion in sales. Among the nations with the smallest franchise sectors include Bulgaria having only 18 franchisors followed by Peru and Chile with 60 and 80 franchisors respectively. In terms of units, Chile and Russia each reported having 300 within their borders while Guatemala was third smallest with more than twice the units of the two smallest sectors at 700. Finally, the smallest sales were reported by Ecuador at $\$ 110$ million followed by Peru (\$218 million), and Guatemala (\$300 million).

The nations with the largest franchising sectors are spread in three of the five regions represented: North America, Asia, and Africa/Oceania while those with the smallest sectors seem to be concentrated in the Americas. These data reveal that franchising has grown considerably. Today there are significant franchising sectors in 5 versus 3 world regions in the early nineties. The growth has been significant even if we examine only those 11 nations common to both this and an earlier study (Preble and Hoffman, 1995). The comparisons reveal that franchising has grown $66 \%$ in terms of median number of franchisors, $117.5 \%$ in median units, and $10 \%$ in terms of median sales. 
What are the major worldwide product/service and geographic markets for franchising?

In this section, we examine the markets both in terms of the economic sectors as well as the geographic regions in which there is currently considerable franchising activity. These data are presented in Table 3. The major business sectors for growth globally are reported to be in restaurants, miscellaneous services, and non-food retailing. Restaurants is the dominant growth sector in all five regions investigated. Miscellaneous services are enjoying growth in South America, Europe, and Africa/Oceania in particular. Retail is described as a leading franchising growth sector in Europe and Africa/Oceania. Franchising appears to be enjoying growth in sectors in which it has traditionally dominated in some of its older markets such as the U.S.A., France, Italy, and Japan. Other less dominant sectors enjoying growth in specific countries included education in Mexico and Thailand; computers/electronics in Brazil; real estate in Czech Republic, Italy and U.K.; consulting in Netherlands; health care in India; and construction in Australia.

\section{"take in Table 3 here"}

Our study also sought to investigate the international expansion of local franchisors abroad as well as the establishment of foreign franchises in each country (i.e., imports). Overall, the franchise associations report the following as the top export markets for their nation's franchising firms: France (14\%), Germany (10\%) and China, Egypt and U.S.A. ( each with 7\% of the mentions), see Table 3. While the global perspective appears to be somewhat surprising, a clearer picture of the franchising export activity can be seen better within regions. The top export markets in each region are usually a nation within that region. Even when there is a major export market out of the region, there are historical or cultural ties between the nations of both regions. For example, in North America, the two top export markets are U.S.A. and Mexico 
within the region. The only non-North American major export market is the United Kingdom, which is a major export market for the U.S.A., its former colony. A similar picture emerges in South America. Argentina and Paraguay are the two major export markets mentioned by the South American nations investigated. Portugal is the only non-South American major export market. Portugal was the former colonizer of Brazil, the country which cites Portugal as one of the major markets to which its franchisors have exported their franchises. Franchising by foreign firms in each country (see Table 3) was also examined. The leading franchise importer was the U.S.A. (42\%) followed by the U.K. (14.5\%), and France (7\%). Of the nations surveyed, the U.S. has the oldest and largest franchising sector. Thus, it is no surprise that its franchising companies have expanded abroad as their markets have become saturated and as the firms have perfected their franchise formats. U.S. franchisors appear to enjoy a first mover advantage in the international expansion of their franchise systems. This is borne out by the franchise import country data (see Table 3). Firms from the U.S.A. are the leading importers of franchise businesses in all but North America, the U.S.'s home region. Apart from the dominance of the U.S.A. in exporting their international franchises, the other major importers are usually from firms located within the region or those from nations with historical or cultural ties to nations within the region. For example, in Europe, after the U.S.A., the leading importers of franchise businesses are from France, Germany, and the U.K. In North America, the leading non-U.S. importers are Canada and Spain while in Africa/Oceania, it is Australia and the U.K.

Taken together, the countries serving as the leading exporters and importers of franchise businesses appear to have either geographic or cultural proximity with the nations in which they are engaging in cross-border franchise expansion as suggested by Johanson and Vahlne (1977) twenty-five years ago and more recently by Ghemawat (2001). To be certain there are 
exceptions in our data, French franchisors are making considerable in- roads in Brazil, and Italian franchisors are cited as a major importer into Japan. Nonetheless, the overall pattern of international expansions by franchising companies appears to be supportive of the geographic and cultural proximity hypothesis.

What are some of the key operational issues for franchisors doing business in different world regions?

While global expansion by franchisors in the countries investigated is readily apparent, we also sought to identify key operational issues franchise companies need to be aware of when doing business in these nations. The operational factors examined include legal, sociocultural, and ethical which Larson (2002) notes as being especially important for companies expanding internationally.

Overall, the trade associations report the existence of royalty taxes, contract law, and the lack of specific franchise legislation as the major legal issues potential franchisors and franchisees needed to be aware of. Existence of royalty taxes appears to be especially prominent in North and South America and Asia. Value added taxes were especially noted by South American and European nations. The existence of contract laws covering franchising was particularly noted in Europe and Asia while the lack of specific franchising legislation was noted by some European nations (ex. Italy, Poland, U.K.) and Egypt as an important legal/tax restriction facing franchisors in these countries. Some other country-specific legal factors favoring franchising include: franchise regulations and subsidiary liability laws in Russia; legal exemptions granted to franchises in Turkey; and funds to promote franchising in Malaysia. Country-specific legal and tax issues restricting franchising include: tariffs in Guatemala and 
Peru; the publicity (advertising) tax in Brazil; rules against foreign recruitment of franchises in China; signage laws in China; and sole supplier legislation in South Africa.

The major social/cultural factors international franchisors need to consider when doing business in any one of the 40 nations investigated include the tastes and habits of the local population as well as the price sensitivity of their consumers. An awareness of taste/habits was the most important socio-cultural issue mentioned in all five geographic regions. Among specific tastes mentioned were: regional/racial differences in U.S.A. and South Africa; modern tastes in Brazil; preference for American lifestyle/products in Canada, Colombia and Ecuador; quality in Germany; and hot and spicy tastes in Thailand. Some of the national habits mentioned included: desire to see/hold product in Dominican Republic; quick service in U.S.A.; sit down meals in France; and bargaining and negotiation are still important business and consumer practices in Egypt and Singapore.

While tastes/habits were important issues noted in all five geographic regions, price sensitivity was particularly important in South America and Egypt in the Africa/Oceania regions. Collectively, these countries reported some of the lowest GDP per capita of our global sample. Thus, pricing would, indeed, be important for consumers in those nations.

Some other socio-cultural characteristics franchisors need to be aware of in various countries include: Austria's leisurely-paced culture; German history and ecology-minded population; religious preferences in China and Thailand; and rapidly changing consumer preferences in Taiwan. Changes affecting marketing practices were also noted in responses to socio-cultural influences that franchising firms need to consider. For example, there is a desire for reliable after-sales service in the Dominican Republic and a need to know the trade practices in Guatemala. The growth of internet use was mentioned by Chile and Czech Republic while 
franchisors should be aware that direct marketing is taking hold in the Czech Republic and Australia. Some of the differences/changes in distribution methods noted include: Italy's distribution structure; the growing use of hyper markets and malls in Poland; the persistence of Russia's black market; and the growing service sector in India. In general, international franchisors need to familiarize themselves with the local culture and methods of conducting business to know how to best adapt their business formats to any given host country. The use of local entrepreneurs as franchisors can help considerably in becoming socially and culturally familiar with local practices.

Ethical business practices that might affect franchising were also investigated. Overall, the two major ethical issues cited were the existence of codes of ethics and the need to conduct business with honesty and trust (see Table 3). The former is not surprising as one of the roles of franchise associations (Preble and Hoffman, 1999) is to help establish self-regulation of the industry through mechanisms such as ethics codes. Honesty and trust were particularly noted in Asia whose countries still rely more on personal connections than contract law as the basis for business transactions (Lovett, Simmons and Kali, 1999). In such situations, trust among the participants is paramount. Conspicuous by the absence of any response to ethical considerations were the South American franchise associations. The lack of response may indicate a lack of concern over such issues or it may indicate that following ethical processes is simply understood among South American businesses. International franchisors need to investigate the attitude of these nations regarding ethical practices prior to entry for their own protection.

Beyond adhering to codes of ethics, the nations that explicitly reported the need to conduct business with high-ethical standards include: Austria, France, Italy, and Taiwan. A 
consideration of ethics ensures that business persons will act beyond merely the letter of the law and make for a more secure business environment.

What are the opportunities and challenges facing franchisors in various parts of the world?

In this final section, we examine some economic opportunities afforded franchisors as well as future challenges affecting franchising in the nations surveyed according to our respondents. Economic opportunity was assessed using a close-ended question. Respondents were asked to indicate the best economic opportunities in their country, based in part on Porter's (1985) competitive strategies. Respondents marked all the applicable opportunities.

These strategic opportunities are depicted in Table 4.

$$
\text { "take in Table } 4 \text { here" }
$$

Globally, the best opportunities are for franchisors offering a low-cost product (35\%); this is followed closely by offering a unique service (33\%); a product combined with a service; a unique product (18\%); and lastly a low-cost service (15\%). Economic opportunities do vary by region. Low-cost products are especially appealing to South America and Africa/Oceania, regions with some of the lowest per capita income. Opportunities for unique services exist in all regions but especially in Africa/Oceania and Asia. Low-cost service opportunities appear to be strongest in North America but almost non-existent in South America. Franchisors offering a product with a service have their strongest opportunities in South America and Asia but little opportunity in Africa/Oceania. Finally, franchisors offering a unique or differentiated product appear to have the best opportunities in Europe especially in Czech Republic, Russia, Turkey, and the United Kingdom. These same franchisors do not appear to have much opportunity in South America or Africa/Oceania. These data should be useful to franchisors contemplating 
expansion into new country markets. Of course, specific products or services may have opportunities in countries that cannot be captured by the broad generic approach to economic opportunities considered in this study.

The last research question focused on open-ended responses to the challenges facing franchising firms operating in the association's country over the next five years. Twenty-eight percent of the survey respondents provided data on the future challenges. The largest number of responses (25\%) revolved around economic issues followed by legal/political challenges (21\%) and franchise management and staff concerns (17\%). Three other issues received an equal proportion of mentions (13\% each) challenges posed by efficiency/innovation, globalization/internet, and socio-cultural issues.

Future challenges mentioned varied by geographic region. North American franchise associations emphasized legal/political challenges (68\%) such as regulations and taxes and the challenges posed by globalization/internet (33\%). In South America, economic issues (66\%), such as stability and energy concerns, represent the greatest future challenges followed by those relating to legal/political issues. European associations reported a wider variety of future challenges. The leading concerns were issues relating to franchise management and staffing (40\%). The rapid growth of franchises has brought about concerns for finding qualified staff and to improve the level of professionalism in the industry. Economic issues relating to competition and anti-trust and globalization/internet challenges each received $20 \%$ of the mentions in this region followed by challenges posed by product innovation and socio-cultural issues (10\% each). Socio-cultural challenges appear to revolve around lifestyle changes leading to cultural developments. In Asia, issues relating to four areas received an equal number of mentions. These were challenges due to economic, legal/political, efficiency/innovation and socio-cultural 
issues. Finally, in the Africa/Oceania region economic issues concerning regulation and competition received the most mentions $-50 \%$ followed by legal/political and socio-cultural issues, each receiving $25 \%$ of the mentions.

The challenges affecting franchising in the future stem from five broad categories of issues. Europeans perceived the greatest variety of challenges covering five of the six issues mentioned. Asians perceive the next widest range of challenging issues (4 of 6 ) followed by Africa/Oceania with challenges relating to half of the issues mentioned. Respondents from the Americas perceive a narrower range of future issues revolving around legal/political, economic, and socio-cultural issues. Although these future issues are described as challenges, they are not all threatening to franchising such as opportunities for innovation, to improve efficiency, to make better use of the internet, and to recruit and train qualified personnel. The regions which have identified a wider variety of challenges may be those regions in which future trends are clearer at present and thus more easily defined. Nevertheless, franchisors seeking to expand into these various world regions now have a better idea of the issues they might face in managing franchises in those locales in the future.

\section{SUMMARY AND LIMITATIONS}

This study provides a profile of seventy-five percent of the nations with an organized franchising sector. This represents a $130 \%$ increase in such nations over seven years ago. These franchise sectors are well distributed over six continents. Franchising has shown considerable growth and development since the early nineties in terms of median franchisors, units, and sales. These results strongly support the growth predictions (e.g., Hoffman and Preble, 1993; Whittmore, 1993) of nearly a decade ago for global franchising. The nations with the most 
franchise activity are primarily urban and middle to upper income countries. These are environments conducive to franchise activity according to the literature (e.g., Preble and Hoffman, 1995).

On average the largest numbers of franchisors are located in North America, Africa/Oceania, and Asia. The major business sectors enjoying worldwide growth in franchise activity include restaurants, retail, and services. These are the industries where franchising has traditionally been strong. The global emergence of services as a growth sector lends support to the observation of Ryans, et al. (1999) that franchising represents an important mode of foreign market entry for services.

International expansion continues to grow with most expansion, be it export or import oriented, to nations within the same geographic region or with previous cultural historical ties to the importing nation. It appears that, in the aggregate, franchisors are giving close consideration to the distance (both geographic and cultural) dimension as suggested in the macro environmental model developed by Alon and Mckee (1999). This model indicates that distance is one of the four critical dimensions that franchisors should assess for choosing a host country. Furthermore, our findings seem to support the geographic/cultural proximity thesis (Ghemawat, 2001; Johanson and Vahlne, 1977). These proximate relationships are particularly important for franchising because of the importance of maintaining standardized practices internationally. Cultural similarity or understanding resulting from proximity can go a long way to enable franchise systems to minimize changes due to country or cultural differences.

Among the major operational concerns franchisors need to be aware of when doing business in the nations surveyed include royalty taxes, contract laws, local tastes and habits, and the existence of codes of ethics in many of the nations. In addition, some laws/regulations 
supporting franchise have been passed and reveal that some governments are encouraging franchising as a means of economic development as others (Amos, 2001; Swartz, 2000) have observed. International economic opportunities appear to be especially abundant for the franchisors offering a low-cost product, a unique service, or a product combined with service. Challenges facing franchsiors in the future include concerns about economic stability and energy, changes in legal/political environments, and the need to find qualified franchisees. Franchising varies by region especially in the size and breadth of the sector itself, the business and geographic markets emphasized, and the economic opportunities available.

This study is limited by its coarse-grained approach to data collection. Data for each nation was obtained from one or two sources in most cases. Some of the data is perceptual and based on estimates. Nonetheless, the respondents and archival sources were deemed to be knowledgeable on the topic. The results provide an overall picture of the global status of franchising.

Future researchers that use these results can improve on these limitations by using larger samples and multiple data sources to explore more deeply some of the issues identified in this study. For example, the cultural and geographic proximity hypotheses might be examined using data on international markets served by franchisors in selected nations. Other research might examine in greater depth franchising sectors of a region or nation again by surveying firms on particular issues of interest such as operational concerns or future challenges facing franchisors in those locales. 


\section{MANAGERIAL IMPLICATIONS AND RECOMMENDATIONS}

The results of this study have implications for both franchise associations and franchisors. Franchise associations may use these results to compare their national activity with that of their region. This comparison can serve as a guide to determine areas and actions for future development of their franchise sector. The association might also see the necessity of taking on the role for systematically tracking and collecting annual data on franchise activity in their region. They could then provide their membership with more accurate information and thereby assist in the members' growth and development efforts.

Franchisors may use the results of this study as a starting point for identifying regions whose characteristics and franchise activity best meet their emerging needs. Target market selection involves three stages (Root, 1994): preliminary screening, identifying perspective target countries, and identifying highest sales potential countries. Our results can assist franchisors in this effort by prescreening regions on the basis of demographic data (Table 1) and the extent of franchising activity (Table 2). Prospective target countries can be narrowed down by examining the cultural and business climate of each region (Table 3 and Table 4 - Challenges). The highest sales potential regions for franchisors can be identified using sales data in Table 2 as well as the economic opportunities identified in Table 4. On the basis of the above analysis, the franchisor would be able to identify a target region, then using Appendix A, the firm can identify specific nations in the region for further screening. Our findings provide a starting point with respect to the country identification decision because specific nations that anchor the range of activity in each region are discussed in some detail in the results section.

The findings of this study have additional implications for franchisors depending on their level of international experience and their business strategies. Using our results along with 
political risk forecasts from sources such as Euromoney, franchisors with little international experience might do well to expand into countries that are either geographically or culturally proximate to their own domestic market and have similar political and economic risk profiles. This facilitates the process of testing their business format in a somewhat familiar and stable new country before expanding into more diverse country markets. Experienced franchisors can venture further afield where new growth opportunities exist. For example, experienced retailing firms might expand to Europe or Africa/Oceania; experienced service firms have growth opportunities in South America, and in health care, opportunities exist in India for experienced firms. Franchisors pursuing a low cost product strategy have the greatest opportunities globally in South America and Africa/Oceania according to our results. Firms offering differentiated services also have significant opportunities globally, especially in Africa/Oceania and Asia. Moreover, firms offering differentiated products would do better to expand into Europe particularly in Eastern Europe.

Finally, our results suggest opportunities for franchisors who wish to launch platform strategies. By expanding first into business friendly environments, firms can then use this as a basis or platform to expand into neighboring countries. For example, nations with few business regulations and existing franchising laws might be considered friendly to franchisors and franchisees alike. Our data suggest that North America and Asia are two such receptive regions. Franchisors might expand into Mexico and use it as a platform to further expand into Central and South America. In Asia, Hong Kong or Japan can be used for further expansion into other Pacific Rim nations. In summary, our results can assist franchisors that want to initiate or extend their international reach. 
This study provides readers with an overview of the current state of franchising globally.

It should serve as a useful starting point for future investigations by both franchising researchers and practitioners interested in the international expansion via franchising.

\section{REFERENCES}

Alon, I. and McKee, D. (1999)," Towards a macro environmental model of international franchising", Multinational Business Review, Vol. VII No.1, pp. 76-82.

Amos, J. H., Jr. (2001), “ Franchising,more than any act of government, will strengthen the global economy", Franchising World, Vol. 33 No. 4, p. 8.

Asia Week (2001), "Special issue: shifting into high gear”, April 4. http://web2.infotrac.galegroup.com/itw/i... Retrieved June 20, 2001.

Chaplin, D. (1998), “Country report - middle east - strategic platform”, Franchise International. http:www.franchise-group.com/fi_mag/ngmiddleeast.html. Retrieved May 7, 2001

Chapman, P. (1997), “'Life-saver in a perilous sea of job losses (Future of Franchising in Europe)".,The European, October 9, p. 39.

Connell, J. (1999), "Diversity in large firm international franchise strategy", Journal of Consumer Marketing, Vol. 16 No. 1, pp. 86-95.

Country Commercial Guides. U.S. State Department. http://www.usatrade.gov/Website/CCG.nsf/. Retrieved November, 2001.

Dixon, T. (2001), Franchise annual, Lewiston, Info Press, New York.

Ghemawat, P. (2001), “ Distance still matters: the hard reality of global expansion”, Harvard Business Review, Vol. 79 No. 8, pp. 137-147.

Hemlock, D. (2000), “ Tips on doing business in Brazil, Florida’s largest trade partner”, Knight Ridder/Tribune Business News (July 17, p Item 00201006).

web2.infotrac.galegroup.com/itw/i... Retrieved May 7, 2001.

Hoffman, R.C. and Preble, J.F. (1993), "Franchising into the twenty-first century", Business Horizons, Vol. 36 No. 6, pp. 35-43. 
Hough, J. (1995), “India has become one of the more important markets”, Feedstuffs, Vol. 67 No. 36, p. 35.

Hunt, J. (2001), “ Orient express (Carrefour's Activity in China”,. Grocer, Vol. 224 No. 7503, pp. 36-37.

IPR Strategic Business Information Database. ( 2001), "Russia: Middle class unlike its western counterparts", February 15. http//web2.infotrac.galegroup.com/itw/i... Retrieved on June $20,2001$.

Johanson, J. and Vahlne, J. (1977), "The internationalization process of the firm: a model of knowledge development and increasing foreign commitments", Journal of International Business Studies, Vol. 8 No. 1, pp. 23-32.

Larson, P.( 2002), "International growth patterns remain strong", Franchising World, April, pp. 6-8

Lovett, S., Simmons, L.C. and Kali, R. (1999), "Guanxi versus the market: ethics and efficiency”, Journal of International Business Studies, Vol. 30 No. 2, pp. 231-248.

"Market research reports", Globus and NTDB. http://www.tradenet.gov/. Retrieved January, 2002

Micklethwait, J., and Wooldridge, A. (2000), A Future Perfect, Crown Business, Random House, Inc., New York.

Montlake, S. (2001), “Enterprise: retail: forget politics. Go shopping”, Asia Week, June 8. Financial Times, Inc. (Item \#pASWK17116713).

Http://web2.infotrac.galegroup.com/itw/i... Retrieved on June 20, 2001.

Porter, M. E. (1985), Competitive Advantage, Free Press, New York.

Preble, J. F., and Hoffman, R.C. (1994), "Competitive advantage through specialty franchising", Journal of Services Marketing, Vol. 8 No. 2, pp. 5-18.

Preble, J. F., and Hoffman, R.C. (2002), "The current state of franchising: a global outlook", in Hoffman, R.C. and Vienna, J.M. (Eds.), Proceedings of the Academy of International Business-Northeast. Salisbury, Maryland, pp. 275-283.

Preble, J. F., and Hoffman, R.C. (1995), "Franchising systems around the globe: a status report”, Journal of Small Business Management, Vol. 33 No. 2, pp. 80-88.

Preble, J. F., and Hoffman, R.C. (1999), “ The nature of ethics codes in franchise associations around the globe", Journal of Business Ethics, Vol. 18 No. 3, pp. 239-253. 
Root, F. R. (1994), Entry Strategies for International Markets, D.C. Heath \& Co., Lexington, Massachusetts.

Ryans, J. K., Lotz, S. and Krampf, R. (1999), "Do master franchisors drive global franchising?" Marketing Management, Vol. 8 No. 2, pp. 32-37.

Samiee, S. (1999), "The internationalization of services: trends, obstacles and issues", Journal of Services Marketing, Vol. 13 No. 4/5, pp. 319-336.

Shane, S. A. (1996), "Why franchise companies expand overseas", Journal of Business Venturing, Vol. 11 No. 2, pp. 73-88.

Swartz, L. N. (2000), “Franchising successfully circles the globe”, Franchising World, Vol. 32 No. 5, pp. 36-37.

Welch, L. S. (1992), "Developments in international franchising”, Journal of Global Marketing, Vol. 6 No. 1-2, pp. 81-96.

Whittemore, M. (1993), “An upbeat forecast for franchising”, Nation's Business, Vol. 81 No. 1,pp. 49-56.

"Your country exports online", World Exports. http://www.world-exports.net/franchising.shtml/. Retrieved November, 2001. 
TABLE 1

Country Statistics

(Medians)

\begin{tabular}{|c|c|c|c|c|c|c|}
\hline & Overall & $\begin{array}{c}\text { North } \\
\text { America }\end{array}$ & $\begin{array}{c}\text { South } \\
\text { America }\end{array}$ & Europe & Asia & $\begin{array}{l}\text { Africa/ } \\
\text { Oceania }\end{array}$ \\
\hline Nations & 40 & 5 & 6 & 14 & 11 & 4 \\
\hline $\begin{array}{l}\text { Population } \\
(000,000)\end{array}$ & $\begin{array}{c}29.5 \\
(38.6-1,270)\end{array}$ & $\begin{array}{c}31.6 \\
(8.6-278)\end{array}$ & $\begin{array}{c}25.7 \\
(13.2-174)\end{array}$ & $\begin{array}{c}27.3 \\
(5.2-145)\end{array}$ & $\begin{array}{c}61.8 \\
(4-1,270)\end{array}$ & $\begin{array}{c}31.5 \\
(3.9-69.5)\end{array}$ \\
\hline $\begin{array}{l}\text { GDP/cap. (\$) } \\
(000)\end{array}$ & $\begin{array}{c}\$ 10,650 \\
(2.2-36.2)\end{array}$ & $\begin{array}{c}\$ 9,100 \\
(3.7-36.2)\end{array}$ & $\begin{array}{c}\$ 6,200 \\
(2.9-10.1)\end{array}$ & $\begin{array}{c}\$ 22,450 \\
(6.2-25.5)\end{array}$ & $\begin{array}{c}\$ 10,300 \\
(2.2-26.5)\end{array}$ & $\begin{array}{c}\$ 13,100 \\
(3.6-23 . \mathrm{k})\end{array}$ \\
\hline Urban (\%) & $\begin{array}{c}74 \\
(21-100)\end{array}$ & $\begin{array}{c}74 \\
(39-77)\end{array}$ & $\begin{array}{c}78 \\
(65-87)\end{array}$ & $\begin{array}{c}75 \\
(64-89)\end{array}$ & $\begin{array}{c}58 \\
(21-100)\end{array}$ & $\begin{array}{c}69 \\
(45-86)\end{array}$ \\
\hline Literacy (\%) & $\begin{array}{c}95 \\
(51-100)\end{array}$ & $\begin{array}{c}90 \\
(64-97)\end{array}$ & $\begin{array}{c}91 \\
(83-95)\end{array}$ & $\begin{array}{c}99 \\
(85-100)\end{array}$ & $\begin{array}{c}94 \\
(52-99)\end{array}$ & $\begin{array}{c}90 \\
(51-100)\end{array}$ \\
\hline $\begin{array}{l}\text { Workforce } \\
\text { in Services } \\
(\%)\end{array}$ & $\begin{array}{c}55 \\
(10-90)\end{array}$ & $\begin{array}{c}56 \\
(14-74)\end{array}$ & $\begin{array}{c}53 \\
(45-64)\end{array}$ & $\begin{array}{c}64 \\
(32-50)\end{array}$ & $\begin{array}{c}31 \\
(10-90)\end{array}$ & $\begin{array}{c}57 \\
(45-73)\end{array}$ \\
\hline Radios/cap. & .44 & .98 & .34 & .49 & .20 & .54 \\
\hline
\end{tabular}


TABLE 2

Global Franchising Statistics

(Medians)

\begin{tabular}{|c|c|c|c|c|c|c|}
\hline & Overall & $\begin{array}{l}\text { North } \\
\text { America }\end{array}$ & $\begin{array}{c}\text { South } \\
\text { America }\end{array}$ & Europe & Asia & $\begin{array}{l}\text { Africa/ } \\
\text { Oceania }\end{array}$ \\
\hline $\begin{array}{l}\text { Year } \\
\text { Association } \\
\text { Founded }\end{array}$ & $\begin{array}{c}1989 \\
(1960-2001)\end{array}$ & $\begin{array}{c}1967 \\
(1960-89)\end{array}$ & $\begin{array}{c}1991 \\
(1981-98)\end{array}$ & $\begin{array}{c}1987 \\
(1971-98)\end{array}$ & $\begin{array}{c}1992 \\
(1972-99)\end{array}$ & $\begin{array}{c}1983 \\
(1979-2001)\end{array}$ \\
\hline $\begin{array}{l}\text { Assn. } \\
\text { Membership }\end{array}$ & $\begin{array}{c}108 \\
(2-1300)\end{array}$ & $\begin{array}{c}500 \\
(250-1300)\end{array}$ & N/A & $\begin{array}{c}80 \\
(2-320)\end{array}$ & $\begin{array}{c}122 \\
(20-200)\end{array}$ & $\begin{array}{c}160 \\
(145-747)\end{array}$ \\
\hline Franchisors & $\begin{array}{c}265 \\
(18-1500)\end{array}$ & $\begin{array}{c}500 \\
(150-1500)\end{array}$ & $\begin{array}{c}80 \\
(60-894)\end{array}$ & $\begin{array}{c}171 \\
(18-810)\end{array}$ & $\begin{array}{c}334 \\
(127-968)\end{array}$ & $\begin{array}{c}400 \\
(286-747)\end{array}$ \\
\hline $\begin{array}{l}\text { Franchise } \\
\text { Units } \\
(\mathbf{k}=000)\end{array}$ & $\begin{array}{c}14,561 \\
(300-316 \mathrm{k})\end{array}$ & $\begin{array}{c}20,000 \\
(700-316 \mathrm{k})\end{array}$ & $\begin{array}{c}1,200 \\
(300-46.5 \mathrm{k})\end{array}$ & $\begin{array}{c}14,250 \\
(300-37 k)\end{array}$ & $\begin{array}{c}24,000 \\
(2 \mathrm{~K}-198 \mathrm{k})\end{array}$ & $\begin{array}{c}14,872 \\
(4 \mathrm{k}-49 \mathrm{k})\end{array}$ \\
\hline $\begin{array}{l}\text { Sales } \mathbf{( \$} \\
\mathbf{0 0 0 , 0 0 0 )} \\
\% \text { change } \\
\text { from } \\
\text { prior year }\end{array}$ & $\begin{array}{l}\$ 3,700 \\
(110-1 \text { tril. })\end{array}$ & $\begin{array}{c}\$ 4,600 \\
(300-1 \text { tril. })\end{array}$ & $\begin{array}{c}\$ 218 \\
(110-420)\end{array}$ & $\begin{array}{c}\$ 7,800 \\
(750- \\
38,000) \\
10 \%\end{array}$ & $\begin{array}{c}\$ 2,400 \\
\text { (110bil. - } \\
\text { 156bil.) } \\
10 \%\end{array}$ & $\begin{array}{c}\$ 8,400 \\
(614-76.5 \\
\text { bil. }) \\
5 \%\end{array}$ \\
\hline
\end{tabular}


TABLE 3

\section{Market and Operational Characteristics}

(Ranked by Frequency)

\begin{tabular}{|c|c|c|c|c|c|c|}
\hline & Overall & $\begin{array}{c}\text { North } \\
\text { America }\end{array}$ & $\begin{array}{c}\text { South } \\
\text { America }\end{array}$ & Europe & Asia & $\begin{array}{c}\text { Africa/ } \\
\text { Oceania }\end{array}$ \\
\hline $\begin{array}{l}\text { Growth } \\
\text { Sectors }\end{array}$ & $\begin{array}{l}\text { Restaurants } \\
(23 \%) \\
\text { Misc. Services } \\
(21 \%) \\
\text { Retail-non food } \\
(19 \%)\end{array}$ & $\begin{array}{l}\text { Rest. }(60 \%) \\
\text { Bus. Services } \\
(20 \%)\end{array}$ & $\begin{array}{l}\text { Rest. (66\%) } \\
\text { Misc. Serv. } \\
(33 \%)\end{array}$ & $\begin{array}{l}\text { Rest. (36\%) } \\
\text { Retail (21\%) } \\
\text { Misc. serv (21\%) }\end{array}$ & $\begin{array}{l}\text { Rest. }(27 \%) \\
6 \text { other sectors }\end{array}$ & $\begin{array}{l}\text { Rest. }(25 \%) \\
\text { Construction } \\
(25 \%) \\
\text { Misc. serv. } \\
(25 \%) \\
\text { Retail }(25 \%) \\
\end{array}$ \\
\hline $\begin{array}{l}\text { Franchise } \\
\text { Export } \\
\text { Nations }\end{array}$ & $\begin{array}{l}\text { France }(14 \%) \\
\text { Germany(10\%) } \\
\text { U.S.A.(7\%) } \\
\text { China }(7 \%) \\
\text { Egypt, }(7 \%) \\
\end{array}$ & $\begin{array}{l}\text { U.S.A. }(20 \%) \\
\text { Mexico }(20 \%) \\
\text { U.K. }(20 \%)\end{array}$ & $\begin{array}{l}\text { Argentina(17\%) } \\
\text { Paraguay (17\%) } \\
\text { Portugal (17\%) }\end{array}$ & $\begin{array}{l}\text { France }(24 \%) \\
\text { Germany }(18 \%) \\
\text { Spain }(12 \%)\end{array}$ & $\begin{array}{l}\text { China }(18 \%) \\
\text { S.E. Asia (9\%) }\end{array}$ & $\begin{array}{l}\text { Africa }(17 \%) \\
\text { Australia (8\%) }\end{array}$ \\
\hline $\begin{array}{l}\text { Franchise } \\
\text { Import } \\
\text { Nations }\end{array}$ & $\begin{array}{l}\text { U.S.A. }(42 \%) \\
\text { U.K. }(15 \%) \\
\text { France }(7 \%)\end{array}$ & $\begin{array}{l}\text { Canada }(22 \%) \\
\text { Spain }(22 \%)\end{array}$ & $\begin{array}{l}\text { U.S.A. }(28 \%) \\
\text { France }(6 \%) \\
\text { U.K. }(6 \%)\end{array}$ & $\begin{array}{l}\text { U.S.A. }(36 \%) \\
\text { U.K. }(20 \%) \\
\text { France }(8 \%) \\
\text { Germany }(8 \%)\end{array}$ & $\begin{array}{l}\text { U.S.A. }(55 \%) \\
\text { Japan }(18 \%) \\
\text { Italy }(9 \%) \\
\text { Singapore }(9 \%)\end{array}$ & $\begin{array}{l}\text { U.S.A. (33\%) } \\
\text { Australia (33\%) } \\
\text { U.K. }(33 \%)\end{array}$ \\
\hline $\begin{array}{l}\text { Tax/legal } \\
\text { Factors }\end{array}$ & $\begin{array}{l}\text { Royalty taxes } \\
(14 \%) \\
\text { Contract laws } \\
(8 \%) \\
\text { No Franchise } \\
\text { laws }(8 \%)\end{array}$ & $\begin{array}{l}\text { Royalty Taxes } \\
(33 \%)\end{array}$ & $\begin{array}{l}\text { Royalty } \\
\text { taxes }(15 \%) \\
\text { V.A.T. }(15 \%) \\
\text { Tariffs }(15 \%)\end{array}$ & $\begin{array}{l}\text { V.A.T. }(20 \%) \\
\text { No Franchise } \\
\text { laws }(20 \%) \\
\text { Contract laws } \\
(20 \%)\end{array}$ & $\begin{array}{l}\text { Royalty taxes } \\
(15 \%) \\
\text { Contract laws } \\
(15 \%)\end{array}$ & Variety of issues \\
\hline $\begin{array}{l}\text { Socio- } \\
\text { cultural } \\
\text { Factors }\end{array}$ & $\begin{array}{l}\text { Tastes, habits } \\
(36 \%) \\
\text { Price sensitive } \\
(9 \%)\end{array}$ & $\begin{array}{l}\text { Tastes, } \\
\quad \text { habits }(38 \%) \\
\text { Commitment } \\
(13 \%) \\
\text { Convenience } \\
(13 \%)\end{array}$ & $\begin{array}{l}\text { Tastes }(44 \%) \\
\text { Price sensitive } \\
(22 \%) \\
\text { Dynamic society } \\
(11 \%)\end{array}$ & Tastes (21\%) & $\begin{array}{l}\text { Tastes }(25 \%) \\
\text { Religion } \\
(25 \%)\end{array}$ & $\begin{array}{l}\text { Tastes }(50 \%) \\
\text { Price sensitive } \\
(25 \%) \\
\text { Currency } \\
\text { depreciation } \\
(25 \%)\end{array}$ \\
\hline $\begin{array}{l}\text { Ethical } \\
\text { Issues }\end{array}$ & $\begin{array}{l}\text { Code of Ethics } \\
(33 \%) \\
\text { Honesty, trust } \\
(22 \%)\end{array}$ & $\begin{array}{l}\text { Code of Ethics } \\
(20 \%)\end{array}$ & N/A & $\begin{array}{l}\text { Code of Ethics } \\
(14 \%) \\
\text { High ethical } \\
\text { practices }(7 \%)\end{array}$ & $\begin{array}{l}\text { Honesty, } \\
\quad \text { trust (9\%) }\end{array}$ & $\begin{array}{l}\text { Corruption } \\
(25 \%)\end{array}$ \\
\hline
\end{tabular}


TABLE 4

Global Franchising Opportunities and Challenges

(\% of Mentions)

\begin{tabular}{|c|c|c|c|c|c|c|}
\hline & Overall & $\begin{array}{c}\text { North } \\
\text { America } \\
\end{array}$ & $\begin{array}{c}\text { South } \\
\text { America }\end{array}$ & Europe & Asia & $\begin{array}{l}\text { Africa/ } \\
\text { Oceania }\end{array}$ \\
\hline \multicolumn{7}{|c|}{ Economic Opportunities: } \\
\hline Low-cost product & $35 \%$ & $25 \%$ & $50 \%$ & $21 \%$ & $25 \%$ & $50 \%$ \\
\hline Low-cost service & $15 \%$ & $25 \%$ & -- & $14 \%$ & $6 \%$ & $17 \%$ \\
\hline Unique product & $18 \%$ & $13 \%$ & -- & $29 \%$ & $13 \%$ & -- \\
\hline Unique service & $33 \%$ & $25 \%$ & $25 \%$ & $21 \%$ & $31 \%$ & $33 \%$ \\
\hline Product with service & $20 \%$ & $13 \%$ & $25 \%$ & $14 \%$ & $25 \%$ & -- \\
\hline \multicolumn{7}{|l|}{ Challenges: } \\
\hline Economic & $25 \%$ & -- & $66 \%$ & $20 \%$ & $25 \%$ & $50 \%$ \\
\hline Legal/political & $21 \%$ & $66 \%$ & $33 \%$ & -- & $25 \%$ & $25 \%$ \\
\hline Franchise Mgt. \& Staff & $17 \%$ & -- & -- & $40 \%$ & -- & -- \\
\hline Efficiency/innovation & $13 \%$ & -- & -- & $10 \%$ & $25 \%$ & -- \\
\hline Globalization/internet & $13 \%$ & $33 \%$ & -- & $20 \%$ & -- & -- \\
\hline Socio-cultural & $13 \%$ & -- & -- & $10 \%$ & $25 \%$ & $25 \%$ \\
\hline
\end{tabular}


Appendix A

Nation s Investigated by Region

\begin{tabular}{|c|c|}
\hline $\begin{array}{l}\text { NORTH AMERICA: } \\
\text { CANADA } \\
\text { DOMINICAN REPUBLIC } \\
\text { GUATEMALA } \\
\text { MEXICO } \\
\text { UNITED STATES }\end{array}$ & $\begin{array}{l}\text { SOUTH AMERICA: } \\
\text { BRAZIL } \\
\text { CHILE } \\
\text { COLOMBIA } \\
\text { ECUADOR } \\
\text { PERU } \\
\text { VENEZUELA }\end{array}$ \\
\hline $\begin{array}{l}\text { EUROPE: } \\
\text { AUSTRIA } \\
\text { BULGARIA } \\
\text { CZECH REPUBLIC } \\
\text { DENMARK } \\
\text { FINLAND } \\
\text { FRANCE } \\
\text { GERMANY } \\
\text { HUNGARY } \\
\text { ITALY } \\
\text { NETHERLANDS } \\
\text { POLAND } \\
\text { RUSSIA } \\
\text { TURKEY } \\
\text { UNITED KINGDOM }\end{array}$ & $\begin{array}{l}\text { ASIA: } \\
\text { CHINA } \\
\text { HONG KONG } \\
\text { INDIA } \\
\text { INDONESIA } \\
\text { ISRAEL } \\
\text { JAPAN } \\
\text { MALAYSIA } \\
\text { PHILIPPINES } \\
\text { SINGAPORE } \\
\text { TAIWAN } \\
\text { THAILAND } \\
\text { AFRICA/OCEANIA: } \\
\text { AUSTRALIA } \\
\text { NEW ZEALAND } \\
\text { EGYPT } \\
\text { SOUTH AFRICA }\end{array}$ \\
\hline
\end{tabular}

